\title{
A Historical Analysis of Poverty Alleviation and the Changing Role of Local Governments in that Process ${ }^{1}$
}

\author{
Assistant Prof. Dr. Zuhal Önez Çetin \\ Uşak University, Faculty of Economics and Administrative Science, The Head of the Local Government Studies, Turkey \\ Email: zuhal.cetin@usak.edu.tr, zuhalonez@gmail.com
}

\section{Doi:10.5901/mjss.2016.v7n5p41}

\section{Abstract}

\begin{abstract}
The world has witnessed a transformation process associated with the drastic changes, with opening up new challenges for humanity. Poverty, as a global problem, occupies the first place among the clusters and challenges of threats within those transformations. At that study, poverty alleviation process in capitalist formations have been analysed with the launch of poverty phenomenon by capitalism. The first objective of the study is the examination of the poverty alleviation initiatives at prior to welfare state period, welfare state golden age period and neo-liberal periods. In this respect, each period's poverty dynamic, fundamental poverty related formations and institutions have been analysed. The second objective of the study is the detailed examination of the local governments' poverty alleviation initiatives at prior to welfare state period, welfare state golden age period and neo-liberal periods. In this context, the changing role of the local governments at poverty alleviation is critically analysed.
\end{abstract}

\section{Introduction}

The world has witnessed a transformation process associated with the drastic changes in social, political, administrative and economic spheres (globalization, geographical restructuring, rescaling of state, re/deterritorialization, re/deindustrialization; mainly covering the contradictions and crisis of capitalism and on the struggle of labor and capital), with opening up new challenges for humanity. Poverty, as a global problem, occupies the first place among the clusters and challenges of threats within those transformations. Poverty has been aggravating day by day in the world-wide with deepening the problems of most vulnerable and disadvantaged sections of the society under the logic of capital accumulation process, and there seems to be little progress at the alleviation of its deteriorative effects, especially at developing countries. According to WB (World Bank) "Global Poverty Indicators", poverty headcount ratio is \%12.7 in 2012, and $\$ 1.90$ a day, people living on less than $\$ 1.90$ a day is 902 million in $2012 .{ }^{2}$ At the other angle, local governments have attributed new responsibilities at poverty related issues as policy makers at combating poverty under the neo-liberal logic. Neo-liberal policies have mostly indicated the nation state as closed, introvert and as an important handicap on capitalist accumulation process by putting the rules in its own separated field and playing the game itself (Güler, 2005: 16-17). In this sense, nation states are now less interventionist and lots of poverty alleviation initiatives are transferred to local governments. Local government based poverty alleviation discourse is started to be highlighted at the recent global gatherings, conferences and their output reports, with "governance and decentralization" arguments under neo-liberal logic after the 1990s, when poverty alleviation is determined as an objective of development assistance. At that focal point, decentralization advocates at poverty struggle argue that "government become closer to the governed both spatially and institutionally, government will be more knowledgeable about and responsive to the needs of the people" (Peterson, 1994). Additionally, they have supported the view that local governments give greater voice and representation of citizens, remove social constraints and administrative obstacles limiting the power of central government, facilitate collective action, make central government more responsive to citizen needs and produce more acceptable government decisions (Bongfiglioli, 2003:45-46). Bardhan (1997) also added that "decision-making at the local level gives more responsibility, ownership, and thus incentives to local agents; monitoring and control of local agents by local communities are easier".

At that study, poverty alleviation process in capitalist formations has been analysed with the launch of poverty

${ }^{1}$ This study has been produced from my PHD dissertation submitted to The Graduate School of Natural And Applied Sciences of Middle East Technical University titled "Critical Evaluation of Local Poverty Alleviation Policies: The Case of Three Provinces In Turkey" in 2012.

${ }^{2}$ For detail, see, Worl Bank Global Poverty Indicators, ( http://povertydata.worldbank.org/poverty/home/). 
phenomenon by capitalism. The first objective of the study is the examination of the poverty alleviation initiatives at prior to welfare state period, welfare state golden age period and neo-liberal periods. In this respect, each period's poverty dynamic, fundamental poverty related formations and institutions have been analysed. The second objective of the study is the detailed examination of the local governments' poverty alleviation initiatives at prior to welfare state period, welfare state golden age period and neo-liberal periods. In this context, the changing role of the local governments at poverty alleviation is critically analysed. Besides, local governments' emergence as a pivot actor at the struggling of poverty has also been searched under new urban politics. At that scope, the document analysis method is used to see the historical transformation of the poverty, poverty alleviation process, and the changing role of the local governments at poverty alleviation. This analysis is determined as a social research method, and it is an important research tool in its own right. It refers to the various procedures involved in analyzing and interpreting data generated from the examination of documents in related with a particular study ${ }^{3}$. Within the context of the study, the documents concerning poverty, poverty alleviation and local administrations' role on poverty alleviation have been used to examine the poverty alleviation initiatives in a historical perspective. The study may be expected to be relevant for illustrating the poverty and poverty alleviation initiatives transition in the historical process and the local authorities role at the alleviation of poverty at prior to welfare state period, welfare state golden age period and neo-liberal periods. The study offers a historical background analysis at the alleviation of poverty and sheds light on the future studies. Consequently, the limitation of the study can be clarified as there is little chance for comparison of different countries' poverty and poverty alleviation initiatives; the data only facilitate to see the historical transformation of poverty alleviation process and the role of local authorities at poverty alleviation.

\section{The Concept of Poverty and Poverty Alleviation}

Poverty is not a new concept; even its history is as old as the history of the human being. However, at the studies and researches concerning poverty, there has been no consensus on an agreed definition. Conceptualizations have different value judgements on their views of the poor and those are changed from one social formation to another in time, making poverty difficult to identify. In this regard, poverty is a multi-facet problem needing urgent solutions for whole nations. The general and the simplest conceptualization of poverty is often determined with the lack of basic needs mostly related with material well-being necessary for survival, and the poor are those who, even in normal circumstances, are unable to feed and clothe themselves properly and at risk of death as a consequence (Macpherson and Silburn, 1998: 1). Besides, poverty is designated as the state of living conditions at not reaching to the sufficient resources to provide a minimum livelihood standard, for particular groups in a defined geographical unit for a certain time period (Mingione, 1992). However, poverty conceptualization has a dynamic structure; it is exposed to change over time and space that new types of poverty categorizations are emerged as to the necessity of shifting conceptualizations (Dikici and Bilgin, 2006).

As a result of the multi-facet character of poverty; sometimes definitions and concepts are overlapped at the determination of the concept. Broader definitions are used by multi-national bodies such as, United Nations (UN), that referring poverty as violation of basic rights and human dignity; UK government used the aspects like "lack of income and access to good quality health, education, housing and the quality of the local environment (Lister, 2004: 5). It can be clearly stated that at the designation of poverty, many factors come together and make the poverty a complex and also a multidimensional social phenomenon which has no single and an exact definition.

For this reason, the definition of the poverty problem is the heart of the right policy formulation and struggling with poverty. Once a problem is recognized, many possible means to alleviate, mitigate, or resolve it may be explored quickly and tentatively ( $\mathrm{Pal}, 1989:$ 4). It is seen that right strategies, methods, policy and program packages are all dependent to designation of poverty. So, it can be clearly stated that right determination of poverty is also affected the poverty alleviation process. At that point, poverty alleviation (reduction) policies formulated to seek to alleviate or eradicate not only the level of poverty and the negative impacts of poverty on the people's livelihoods, but also the percentage of people living in poverty by macro or micro level governments. In that scope, developing countries achievement of success at the alleviation of poverty is a difficult process. It is determined that poverty alleviation is generally used a short-hand for promoting economic growth. However, poverty alleviation have diverse objectives and to make choices among those different targets is hard for most of the developing nations. ${ }^{4}$ Consequently, the central and local governments' formulation of poverty, the role of the local governments at the achievement of those determined targets is influential in achieving the success at the poverty alleviation process.

${ }^{3}$ For details, see, "Document Analysis" (http://www.drcath.net/toolkit/document.html).

${ }^{4}$ For details, see, (http://www.cgdev.org/files/1421599_file_Barder_Poverty_Reduction.pdf). 


\section{An Historical Analysis of Poverty Alleviation and the Role of Local Governments}

\subsection{Poverty Alleviation Before Welfare State Period and the Role of Local Governments:}

Prior to industrialization phase by 1880 onwards, the civil society (family and community), religious institutions, voluntary organizations, professional associations, and mutual aid foundations provided social welfare services to the poor in an informal way. At that period, people's requirements and expectations were not at a high level that until the start of the industrialization period, social based tasks were largely fulfilled by those formations (Özdemir, 2007: 107). In that context, in most of the nations, particularly in western nations, during the traditional social policy period, church played a central role in coping with social problems. Especially in Middle Ages, charitable organizations such as patient homes, soup kitchens, and monastries were the basic aid agencies of the community, which were founded by church (Güzel and Okur, 1990: 16-17). Besides, in Middle Ages, at the society, moral values were dominant that gaining extreme fortune perceived as not good by the society. In this sense, peoples' spending for social services mostly rises their reputation that socialtarget charitable expenditures was quite a lot during that period. Critically, modern poverty phenomenon peculiar to capitalism emerged during $16^{\text {th }}$ century in Europe. That period had confronted with the transition of traditional agricultural societies, and that process was leading to spatial mobility which originating uncertainties and unrest. At such an environment, in comparison to the previous periods, poverty nature had changed in livability and perceivement terms (Buğra, 2008: 24). Today, the way we discussed poverty as a social and also as an economic problem is linked to the emergence of capitalism at $16^{\text {th }}$ century in Europe. In that context, the poor had provided the welfare for the souls of the rich; beggary and benevolence were the fundamental parts of that social order. However, in the early modern age, poverty conceptualization demonstrated a change in the attributed social role to the impoverished. The facts of poverty was started to be explained by not integrating to labor market and in $16^{\text {th }}$ century begging had no gained warm reception within the capitalist labor centered value system. The effort at integrating the impoverished to the labor market was strengthened at early capitalist value system. At the poverty alleviation argument that period is limited with supporting and legitimizing the existed order by seeing human being as labor and the prevention of beggary and benevolence are the basic tools at combating poverty (Buğra, 2008: 25-26). By $16^{\text {th }}$ century onwards, in addition to church's dominant role at social policies, state founded institutions started to deal with social and economic problems. For the first time, public power was used for social target based issues and on that direction at various periods 'Poor Laws' had been started to be enforced (Çalışkan, 2001: 24). In this respect, The Poor Law Act application introduced by Queen Elizabeth in 1601, and it can be emphasized as the first law at the provision of social support to specific groups (the elderly and the ill health people), except soldiers. Previously, there were also some other laws dated 1388 with a similar name of 'Poverty Law', however, the main purpose of that law was dealing with the plague occured in the potential labor shortage. Under the scope of the law, it was stated that people who need of help can be placed to 'house of correction'. At the context of that related Act, government responsibility was highlighted clearly at poverty problem and public power had gained liability at ensuring the economic well-being of individuals. Law had also included items reffering that beggars who can work must be forced to employ at light works and imprisonment penalty must be given of those who refuse to work. Besides at the Law context, it was emphasized that to help beggars has to be prohibited, lastly the elderly, the blind, the deaf, the disabled and the women with children if unable to work have to be hosted at 'Almshouse' (Ersöz, 2003:8).

Furthermore, $16^{\text {th }}$ century 'alms reform' was not ignorant to the labor market necessities but the prior target was protecting cities from the impoverished. At that term 'workhouses' were set up with the aim of sheltering and working healthy poor. Those institutions object was not only production but discipline and decency for the treatment of moral decay of the poor through employment. Later a more systematic and rational effort came with a new approach towards the poor at the last period of $17^{\text {th }}$ century. That approach was emphasizing the need for reform concerning the institutions employed the impoverished. John Bellars at the end of $17^{\text {th }}$ century and Jeremy Bentham until the beginning of the $19^{\text {th }}$ century are the main supporters of that new approach on poverty. However at the last period of $18^{\text {th }}$ century with Industrial Revolution and the subsequent free market economy conditions, 'New Poor Act' (1834) in England signed out as a new turnover. Previous poor act had ruled more than 200 years but industrialization came out earlier in England compared to other countries with affecting community badly in economic terms. The transition in economic and philosophical thought let the enactment of a new 'Poverty Law'. The main principle of that law was including a more powerful 'income test' to the system and it had the target of refraining from the provision of poor assistance to the impoverished (Koray, 2003: 95). During that period, the effect of Adam Smith and free-market mechanism was obvious (Özdemir, 2007: 142). In this regard, 'New Poor Act' was undisputed a victory for $19^{\text {th }}$ century liberals, earlier Poor Acts were settling upon the creation of tight steps to strengthen social rights of the poor but the new law act was focusing on to assist the poor by taking away the civil rights in their hands (Marshall, 1964: 56). In spite of the 'Poor Act', during $19^{\text {th }}$ 
century, social based policies started to emerge by the launch of industrialization and capitalist transitional mode of production. At that phase, urbanization had an accelerating dynamic and in political dimension working class started to gain political consciousness. In particular, the previous term's social assistance institutions (family and charity organizations) could not meet the demands of the impoverished that new institutions necessity came to the front side to meet such requirements. At that point, traditional social welfare agencies could not respond to meet the needs of health care and work injuries of the labor working at the urban scale (Koray, 2003: 95). By the weakening of traditional social protection mechanisms and also the change at family structure concerning fragmentation of family ties, particularly at industrialized nations, most of the social based responsibilities have taken over by the state (Güloğlu, 1998: 36). However, at the age of industrialization, the state had been following the liberal philosophy by not intervening to market economy for ensuring the development of trade and industry and preferred to remain passive at social based problems. Absolute freedom, such as personal and political rights are the foregrounds of this period but with the rise at the poverty statistics, it led to criticisms that social welfare state material foundations started to emerge (Bulut, 2001: 3). As a result, interventionist state approach came out with the assumption that market cannot adjust itself that state has to ensure full employment and for a balanced development of economic and social life, state should directly participate to the economic system. In this regard, social based policies applications have been started to be submitted since the early 1870s and for the first time at the beginning of 1880s, Bismarck imposed 'social security regulation' in Germany. Social policies applications have been spreaded to surrounding countries, most importantly, at United Kingdom in 1908, social security system began related to illness and unemployment, and a new social security system initiated by the preparation of Beveridge Report (Dilnot, 2003: 2-3). After the Great Economic Depression in 1929, the liberal state is started to be seen as a failure. Besides, economic crisis in US spreaded to the economies of other countries and to avoid the problems of unemployment and poverty, interventionist Keynesian economy began to be pursued with full employment and Keynesian demand management policies (Sözer, 1994). Consequently, prior to the welfare state applications; at poverty alleviation dynamic, there has been no systematic local based poverty policy formulation at the local administrative framework, the domination is at individual, philanthropic values, and state responsibilities were changed by the enforced several 'Poor Acts'.

\subsection{Poverty Alleviation at Welfare State Period and the Role of Local Governments:}

Capitalism crisis in the history of the 1929 was ground-breaking at ending the guiding rule of 'every supply creates its own demand'. Classical liberalism design of economic and social order to render itself did not give the expected results in real life, free competition in market economy replaced by monopolies and contradictions. In that context, US national income fell by one third between the years 1929-1933; millions of people lost their jobs. With World Economic Depression, then World War II, most of the nations came up with the abandoning of the classical paradigm that has the view of markets adjust in the long term. Assumption is turned towards governments needed to play a role in regulating and developing their economies and laissez faire paradigm could not operate with only an 'invisible hand'. At that point, De Regil (2001: 3) emphasized that "it was now the belief that a real hand needed to serve as a countervailing element to control its cycles and any speculative abuses". In this regard, 'Keynesianism' comes to the front side that provides the expansion of welfare services and policies, particularly at European nations. Welfare state becomes an instrument at the formulation of macro-economic policies, such as at investments in health, education, transformation, and communication (Mullard and Spicker, 1998: 18-23).

The similar point for whole nations was the key role of state at the accumulation process and the difference lies at while at the developed countries, state takes the responsibility of the orientation of the capital resulting from overaccumulation, underdeveloped countries faced with limited capital accumulation problem (Harvey, 1985). After those clarifications, it is beneficial to put forth the link with welfare state and poverty alleviation, starting with a brief definition of welfare state;

It is a category of state, consciously used for the organized public power for alleviating the roles of market powers (Briggs, 1999); functioning around those three principal elements; a guarantee of minimum standards, including an income guarantee for individuals and households; social protection in the event of insecurity to recover the social risks (illness, unemployment etc..); the provision of social welfare services (Briggs, 1961).

In this sense, in the analysis of Keynesian theory at the evaluation of poverty in detail, Keynesian Welfare State Model (KWSM)'s key determinants are determined as follows;

- Among the formal organizations of various scales, the level of nation state was considered to be the dominant 
scale. Local and regional authorities have been functioning as the main transmission belts for national economy and social policies. From that key principle, it is observed that local authorities remarked with their complementary roles at social policies.

- International market economy is evaluated as nothing more than the financial and commercial flows among various national economies. Demand management of Keynesian economics has a critical role at recovering the instability and economic booms at market-economy. At the alleviation of poverty and unemployment, state takes over responsibility by money, tax, and income transfer policies. Local and regional economies are adopted as sub-units of national economies by ignoring inter-regional diversities and differences (Jessop, 2005: 308). As it was clearly seen that nation state has a pure responsibility at combating poverty.

- State intervention to market economy has two objectives; firstly the provision of economic development, by full-employment with softening labor-employer relations via the social welfare programs and controlling labour market (negotiation between labor and capital for relieving social unrest), secondly realization of infrastructure, housing, and transportation investments, provision of basic social services to whole society and development of income transfer policies related to under classes. Briefly, at the provision of social welfare related with poverty alleviation, state decisive functions can be listed as follows;

i. Assistances and aids towards the impoverished,

ii. Ensuring the welfare of individual in the fields of education and health,

iii. Provision of full-employment,

iv. Nationalization of basic industrial branches such as energy, telecommunication, transportation, and infrastructure,

v. Fair taxation (progressive taxation) of inequalities at the distribution of income as an output of free-market and provision of social insurance system to protect whole society from the risks.

vi. Application of positive discrimination programs to the children, youth, women, immigrants, and minorities (Sallan Gül, 2006: 150, Tuna and Yalçıntaş, 1988: 129).

Social based applications of Keynesian Welfare State, critical at the alleviation of poverty, are composed of social insurance service programs and methods that publicly provided and transfer payments. Social security or social insurance system is an influential ingredient at the institutionalization of Keynesian perception. In that context, the basic principle that forms Keynesian welfare state is the supporting of welfare agenda with economic, political, and administrative programs. Welfare state is transformed into a public power, with the designation of a wide-spread consensus area by its three important components. Firstly, a minimum income is guaranteed with not taking into account the individuals or households estate ownership and economic value of their professional gainings. Secondly, state has targeting to provide insurances concerning the risks towards ill health, disability, unemployment, and old age with the most qualified standards without making any discrimination related to class and statute. Besides, social assistance without premium payment which is provided by the state is tied to the condition of being poor and it is defined by meanstested. Those services have universal character, the quantity of assistance, its provisions and conditions are defined by law. Prior to Keynesian period, those assistances were provided by regional or voluntary organizations with not taking charge from school education, provision of free book and fellowships, and delivery of free- meal (Barr and Coulter, 1991: 276).

After the clarification of that general outlook, the local governments' initiatives of welfare state period will also be analyzed. Urban areas, cities are the fields of collective consumption. At the center of urban development, there is the labor power reproduction and in developed countries the organization is made by welfare state but in underdeveloped countries that responsibility is realized by local groups because of state's limited intervention to the urban area (Şengül, 2004: 190-191). At the other side, underdeveloped nations faced with under-investment problem at the urban areas due to the limited capital accumulation problem. Resources are firstly oriented towards industrialization that creating problems at infrastructure and collective consumption. Local governments' strength was also different in developed and developing nations at the poverty alleviation process. At the developed countries, state sensitive intervention to the urban area led to the strengthening of local government. The realization of education, health, housing services at the urban area created the necessity of the organization of local government. Local government became an important part of the central government but most of the scholars have the idea that economic strenght is not diverted to the political field and local government at the political field left behind after the central authority (Cockburn, 1977; Cochrane, 1993). However, in underdeveloped countries, the limited intervention of state to the urban area resulted with the underdevelopment of local government at the economic field. That period was the time of rapid industrialization that increased the pressure on local governments and conflictual relations occurred between local and central governments, and with the effect of those conflicts, local governments became important actors at political arena (Şengül, 2004: 192). As it was mentioned above 
local government particularly at developed countries, became an influential player mostly in economic terms at poverty alleviation concerning the collective consumption based services. However, in developing countries, local governments became a struggling arena at politics and populist policies emerged which are also related with poverty alleviation for grasping the votes of the urban poors at local elections at that period.

\subsection{Poverty Alleviation at Neo-Liberal Period and the Role of Local Governments:}

After the end of welfare state with the collapse of the golden age, particularly at developed countries, governments' social expenditure pies increase at their national budgets; and it is evaluated as the weakening competition power of nations (SPO, 2001: 12). Those nations oriented to restrict and to cutback their social welfare state spending, and to develop new policies to enhance their budgets. All attentions turned towards public expenditures, especially on social spending, and a new tendency is emerged from institutional welfare state towards the residual one (Kuhnle and Alestalo, 2000: 3). At such a socio-eonomic context, neo-liberalism as an alternative of Keynesian and other statist economy policies, came to the front side with finding a wide effective field, by dwelling upon the primacy of individualism, market liberalism and out-ward orientation. At that point, 'neo-liberal strategy' covers overall economy policies that meet the demands and the needs of capital after 1980s. As in the direction of that strategy for the profit of the capital; all kinds of social, administrative, and legal restrictions were abolished. Besides, labor class legal working conditions, their rights concerning unions, social services, and democratic achievements elimination came to the nations' agendas at the worldwide (Savran, 1996: 49). At such a soci-economic context, economic roles of state are determined as defining property rights, enforcing contracts, and regulating the money supply. Besides, there have been also suspicious views concerning the intervention of state to correct market failures; advocaters of neo-liberal policies assumed that state intervention can create more problems than it solves (Kotz, 2000: 1-2). In that context, the policy recommendations of neoliberalism include deregulation of business, privatization of public activities and assets, elimination of/or cutbacks in social welfare programs, reduction of taxes on businesses, elimination bureaucratic red tape, increase at efficiency and productivity (Harvey, 2005: 67-68).

After those clarifications, for setting up the bridge with local governments and poverty alleviation the term covering from 1980s to 1990s onwards has been analyzed by First and Second Generation Structural reforms of Bretton Woods' institutions ${ }^{5}$ within the context of neo-liberalism. By 1980 onwards, First Generation of Structural Reforms or economicfinancial liberation wave emerged, targeted towards reduction of the responsibility and functioning area of state. Reform's economic and political tools are deregulation and privatization. Besides, during 1990s, Second Generation Structural Reforms as political and administrative liberation dynamics came to the agenda under the motto of enabling state and governance. Transformation's first period began in the 1980s carried on to the late 1990s corresponding to the Structural Adjustment Policies' (SAPs) economic and financial liberalization policies, that term is mostly defined as I. Generation Structural Reforms wave (Köse, 2005: 38). At neo-liberal political economy the notion was based on 'minimal state' confined with securing law and order, macro-economic stability, and the provision of physical infrastructure (Öniş, 2003: 1-2). Weak economic performance clarified as the fault of heavy state interventionism and multinational agencies emphasized that market should be liberated from the controls and interventionism of public sectors under the reform process. At that context, Öniş (2003: 3) emphasized that;

The central tenet of neo-liberal thinking based upon 'Washington Consensus' having universal policy proposal of was to pursue a systematic program of decreasing state involvement in the economy through trade liberalization, privatization and reduced public spending, freeing key relative prices such as interest rates and exchange rates and lifting exchange controls.

Moreover, state transformation under neo-liberalism dictated under the guise of debt management to the less developed countries. International Monetary Fund (IMF) and WB loans since the 1980s turned to the form of a common function providing economic and financial discipline of the under- developed and developing nations' economies. Multinational organizations target is not only the provision of credit but adapting economies of those countries to the changing conditions. Liberalization of market, export promotion, cutbacks in government spending, privatization of public enterprises, reduction of bureaucracy in terms of state functions submitted as the mission and realized by SAPs (Ellwood, 2002: 45 and Güler, 2005: 83). Basic policy reforms were applied by multi-national corporations under their declared target as assisting developing countries at overcoming crisis with granting credits to them conditionally. SAPs are mostly submitted as a result of import substitution industrial regimes governments' faults, on the perception that government

${ }^{5}$ The Bretton Woods Institutions are the World Bank, and the International Monetary Fund (IMF). <http://www.brettonwoodsproject. org/item.shtml?x=320747> 
interventions to market mechanism must be reduced for recovering those failures (Hayami, 2003: 3). Most of the developing countries are urged to adopt policies covering economic restructuring and liberalization of institutional formation by multi-national organizations.

Governments abolished their interventionist development policies and adopted new policies in related with the fragmentation of interventionist formation and privatization of state economic enterprises that need subvention. Furthermore, the accumulated debt problem of developing economies urged them to grasp more pie by the help of export strategies at the global market (Keyder, 2004: 34). However, those policies raised the rate of poverty at developing nations, and those nations faced with major financial debt burden. Nation states' diminished role and power at economic and social dimensions hardened the condition of the vulnerable individuals and groups' livelihoods, particularly at developing nations. Insufficiencies of the impoverished at infrastructure, education, health, housing services and employment opportunities were stemmed mostly from excessive foreign debt and liberal macro-economic administrative system (Chossudousky, 1999; 15-16). At that point Ersoy and Şengül (2001: 9, 2003: 1) clarified that;

\begin{abstract}
At the deepening of poverty in this era, neo-liberal policies that have been imposed to less-developed countries by WB and IMF have an influential role. WB and IMF technically shape the poverty problem's context, determination and its acquired dimensions around their own interests and propose to the tools to alleviate poverty with the target of not the politicization of the problem. In that context, while nation states' 'social state' nature has been rapidly eliminating, as a part of those policies unemployed working class have been deprived from education, health, transportation and unemployment assistances of the state.
\end{abstract}

At that transformative process, the labor lost their privileges and powers', and it led to the origination of the inclusion and exclusion dialectic. The new ideological atmosphere enables unemployment, lay-offs, sweat-shops, as well as damages the living standards of the impoverished by widening the gap between the poor and the non-poor with the inequality at the distribution of income. In this respect, not only formal employment opportunities and real-wages have diminished; but also achievements of social security and pension rights were dissolved at that socio-political environment (Keyder, 2004: 35-36). Besides, at the golden period of SAPs covering the term from 1987 to 1996, in Sub-Saharan Africa and Latin America, the number of the people living below the poverty line increased by one third (World Bank, World Development Report 2000/2001: 23). Most of neo-liberal policies enacted are not leading to material welfare and improvement for the impoverished (Şenkal, 2005: 401). In this respect, period is mostly regarded as a lost decade as to the challenging economic growth problems and social based concerns with the cutbacks at social spending that adversely affected the impoverished. Developing countries have faced with the increase at income inequality, wage differentials among skilled and unskilled labor within that neo-liberal environment ${ }^{6}$. By Washington Consensus under SAPs, it is hoped for a trickle down effect mainly for poverty alleviation by the help of economic development and growth, but dissatisfaction and public impatience came afterwards. 'Washington Consensus' was short-lived and it began to be questioned during the early 1990s. Furthermore, multi-national corporations applied programs depending upon the restriction of social services increased poverty rates of the groups who need social service provision during crisis. As a result of that deterioration, trust towards global multi-national corporations diminished owing to the increase at poverty rates. After Asian crisis, most of the country put forward the proposal that "international financial system should be restructured under the target of provision of human development" (Selamoğlu, 2000: 47-48). A noticeable shift appeared at the policy focus of key Bretton Woods institutions in the 1990s onwards, away from a hard-core neo-liberalism, to a new kind of synthesis designated as 'Post-Washington Consensus' (Öniş, 2003: 14).

Within the context of II. Generation Structural Reforms as the advanced stage of neo-liberal state project, a new package is provided for countries that are still in need of debt due to the financial shortage by urging them to accept the proposed program. At that stage, global capitalism started to be institutionalized at nation states and it entered into the second wave of structural reforms of political and administrative liberation process (Güler, 2003: 1). IMF and WB in this period have increased the impact at the political and administrative formations of nation states. Minimal state assumption of deregulation period at I. Generation Structural reforms is transformed to 'enabling state' discourse. The liquidated development character of state re-constructed with its regulatory character; the new role of regulatory state is determined as coordination and control of market activities (Bayramoğlu, 2005: 53). Besides, by the emergence of second reform process, a new administrative model is suggested as 'governance' generally defined as;

The sum of many ways individuals and institutions, public and private, to manage their common affairs. It is an

${ }^{6}$ For detail, see, Basseterre, St. Kitts and Nevis, 2002. The Impact Of Structural Adjustment On The Poor, Paper prepared for the Eastern Caribbean Central Bank Seventh Annual Development Conference, <http://www.caribank.org/titanweb/cdb/webcms.nsf/AllDoc/ 082CC59DA21706 B00425741E00535A3A/ \$File/StrucAdj[1].pdfs. 
evolving process through which conflicting or diverse interests may be accommodated and cooperative action may be taken. It includes formal institutions and regimes empowered to enforce compliance, as well as informal arrangements that people and institutions either have agreed to or perceive to be in their interest (Sala, 2001: 1).

One other meaning of governance is designated as 'administration without government'. Rosenau (1992: 13) emphasized that the new governing type argument is put forth relation between equalities rather than hierarchy at bureaucracy, the ruled and ruling. New administrative model under those trasformative arena is focusing upon the provision of a fragmented and decentralized political power model at the nation-state level, and at the international scale it puts forth the centralization of global capital at the hands of the political power of international and global formations, regional blocks (Bayramoğlu, 2005). Besides, by governance; participation, decentralization, localization, accountability, civic engagement, transparency principles ${ }^{7}$ are entered into the poverty alleviation discourse; mainly let to the transition of lots of responsibilities (concerning also poverty) to local governments. State's new formation can be captured from WDR 1997 with those clarifications;

Development -economic, social, and sustainable- without an effective state is impossible. It is increasingly recognized that an effective state -not a minimal one- is central to economic and social development, but more as partner and facilitator than as director. States should work to complement markets, not replace them (WB, 1997: 18).

Moreover, another pecularity concerning second-wave reform under Post-Washington Consensus is poverty alleviation. It is started to be designated as an objective of development assistance. Trickle-down approach cannot bring the hoped benefit at poverty alleviation particularly at equity concerns that non-market instruments started to be engaged as social and human dimension of adjustment at struggling poverty. In this sense, empowerment and participation of the poor become one of the main pillars of that new approach (Hayami, 2003: 21). New paradigm's reflection can be found in WDR 2000, at Attacking Poverty Report. Poverty alleviation is mostly evaluated by human development terms. Report generally proposes an effective 'Poverty Alleviation Strategy' comprises three dimensions such as promoting opportunity, facilitating empowerment and enhancing security for attacking poverty (World Bank, 2000/01: 6-7, 32, 38-40). In those dimensions; the decentralized poverty alleviation and the increased role of the local governments have also been determined in a critical way. On the other side, by the application of neo-liberal policies, the nature of urban poverty has changed and new urban poverty problem emerged with covering the relative aspects of poverty, such as social exclusion, vulnerability, and powerlessness. In such a socio-economic environment, urban politics has also altered with affecting the local governments' role at poverty struggle. Local administrative bodies have attributed responsibilities at combating poverty but the required power transition is not realized that created problems at the alleviation of poverty. At that point, Peck and Tickell (1994: 324-325) argue that "below the nation-state, local regulatory systems (particularly local states) have been conferred responsibility without power... Above the nation state, supra-national regulatory systems have inherited power without responsibility".

Besides, while most of the local governments have confronted with problems concerning financial, technical, and administrative dimensions at poverty struggle; those administrative formations have found themselves at such a competitive urban environment where it is harder to combat with poverty because at urban politics it signals a decline in the welfarist conception of local government and the rising influence of the market choice concept (Pickvance and Preteceille, 1991). A shift in urban politics has occurred after new administrative discourse of governance. A new urban politics is emerged under enabling-state argument away from the management of public services and the provision of local welfare services to the promotion of economic competitiveness, place marketing to attract inward investment, and support for the development of indigenous private sector firms (Painter, 1998:260). This shift at urban politics is named as Urban Entrepreneurialism. At that poit, Harvey (1989:7) designated that concept as follows "urban entrepreneurialism can be defined through two basic characteristics; firstly, a political prioritization of pro-growth local economic development and secondly, an associated organizational and institutional shift from urban government and urban governance". As it is seen from the clarifications, the notion of urban entrepreneurialism as being a new kind of local economic policy is at the hearth of the new urban politics. The metaphor of the city as a growth machine (Logan and Molotch, 1987: 5), marshalling its resources in the pursuit of economic growth, has thus been utilized by many commentators seeking to document the way in which the local government has undergone a conceptual reorientation as it strives to promote capital accumulation within its boundaries. In this sense, Logan and Molotch (1987: 5) have stated that "entrepreneurial strategies generally favour development and growth over the redistribution of wealth and opportunity, the result can only be a net transfer of wealth from the less well-off to urban elites". Similarly, Harvey (1989) has suggested that entrepreneurial policies

${ }^{7}$ For detail, see, Fikret Toksöz, 2008, Good Governance> Improving uality of Life, TESEV Publicaions 
constitute a subsidy for the affluent at the cost of welfare for the poor. Entrepreneurial strategies have been implicated in the creation of a new urban under-class (Hambleton, 1991; Galgster, 1992), resulting in the so-called dual city (Mollenkopf and Castells, 1991). Consequently, as it is seen from the clarifications while local governments come out as the influential actors in the urban politics on the struggle with new urban poverty at the improvement of their well-being; at the other side they have been integrated to a urban competition to attract more pie from the capital accumulation process that creating tension at the provision of welfare services to the vulnerable side of the society.

\section{Conclusion}

Poverty, as a global problem, occupies the first place among the clusters and challenges of threats within those transformations. Poverty has been aggravating day by day in the world-wide with deepening the problems of most vulnerable and disadvantaged sections of the society under the logic of capital accumulation process, and there seems to be little progress at the alleviation of its deteriorative effects, especially at developing countries. Within the framework of the study, the efforts to alleviate poverty within the socio-economic transformation of the capitalist system is analysed with focusing on poverty alleviation and the role of local governments' in that framework. At the prior period of the welfare state, it is observed that there have been no systematic local poverty policy formulations; philanthropic and individual based policies had an overwhelming influence at combating poverty. State's role at struggling poverty changed with the enforced Poor Acts at that related time period. At the welfare state period, at the provision of welfare, state provided decisive functions at poverty alleviation. Free-charge health assistance, provision of shelter for the impoverished, family allowances, assistances towards the elderly, the disabled, the unemployed, the orphans can be counted as the social assistance tools of the state. However, developed and developing countries poverty alleviation practices and the role of local governments on that process is different. At the developed countries state's intervention to the urban area lead to the strengthening of local government, on the other side at the developing nations, the limited intervention of state resulted with the underdevelopment of local government in the economic dimension (Şengül, 2004: 192).

By 1980s onwards, neo-liberal economy policies came to the front side with the policies that meet the demands of capital. By neo-liberalism and its hegemonic expression of globalization, state has been re-structured under the logic of new political and administrative process, and started to transfer its powers downwards to the local governments with the new rhetoric on state as 'enabling state' and the new administrative model of governance with its principles of decentralization, participation and localization. Besides, at the neo-liberal framework, First and Second Generation of Structural Reforms emerged and affected the poverty alleviation policies nature and context. I. Generation Structural Reforms wave comprised of SAPs with 'minimal state' argument raised the rate of poverty at developing countries, that are urged to adopt neo-liberal policies including restructuring and liberalization of institutional formation. At that phase, it is hoped for a trickle down effect at poverty problem with the economic development and growth, but the hoped benefits not came afterwards. During 1990s, a noticeable shift occurred at the policy fields of the multi-national organizations. With the enabling state argument, a new administrative discourse suggested with 'governance' comprise of participation, decentralization, localization, accountability and transparency principles. In this respect, poverty alleviation discourse has also been changed by the increase of the responsibilities of local governments. Besides, a critical point here is that is related with the integration of the social and human dimensions of poverty to the poverty alleviation policies such as facilitating empowerment (increasing participation of the poor to the political process) policy proposal of the WB 'Attacking Poverty Report'. Finally, it has also seen that urban poverty context and nature are changed with the application of neoliberal policies. Local governments found themselves at a competitive environment where it is harder to fight with poverty (Pickvance and Preteceille, 1991). By the transition of new urban politics, with the rise of the entrepreneurial strategies, local authorities integrated into urban competition where it is hard to provide welfare services to the impoverished. Local administrative bodies have attributed responsibilities at combating poverty but the required power transition is not realized that created problems at the alleviation of poverty. So that as a concluding remark, it can be stated that local governments should be furnished with the required technical, financial and expert staff at the alleviation of the poverty process consistent with their increased responsibilities.

\section{References}

Bardhan, Pranab, 1997. The Role of Governance in Economic Development: A Political Economy Approach. Organisation for Economic Co-Operation and Development, OECD Development Center, Paris.

Barr, Nicholas and Fiona Coulter, 1991. "Social Security: Solution or Problem", (ed.) J.Hills, The State of Welfare-The Welfare State in Britain since 1974, Oxford: Clarendon Press, pp.274-337.Bongfiglioli, Angelo, 2003. "Local Governance for Poverty Reduction, 
Empowering The Poor", United Nations Capital Development Fund Publications.

Bayramoğlu, Sonay, 2005. Yönetişim Zihniyeti, İstanbul: Iletişim Yayınları.

Briggs, Asa, 1961. "The Welfare State in historical perspective", European Journal of Sociology. Vol.2, Issue 2. pp.221-258.

Briggs, Asa, 1999. "The Welfare State at Historical Perspective", Archives Europeennes de Sociologie, Vol.: 2, Issue: 2, pp. 221-259.

Buğra, Ayşe. 2008. Kapitalizm, Yoksulluk ve Türkiye'de Sosyal Politika. İstanbul: İletişim Yayıncılık.

Bulut, Nihat, 2001. "Sosyal Devletin Düşünsel Temelleri ve Çağdaş Sosyal Devlet Anlayışı", Sosyal Devletin Düşünsel Temelleri ve Çağdaş Sosyal Devlet Anlayışı, Prof.Dr.Turan Tufan Yüce'ye Armağan, Dokuz Eylül Üniversitesi Yayını, İzmir.

Chossudovsky, Michel, 1999. Yoksulluğun Küreselleşmesi, IMF ve WB Reformlarının İç Yüzü (çev. N.Sapan), İstanbul: Çiviyazıları Yayınları.

Cochrane, Allan, 1993. Whatever Happened to Local Government, Buckingham: Open University Press.

Cockburn, Cynthia, 1977. Local State. London: Pluto.

Çalışkan, Abdülkerim, 2001. "Sosyal Refahın Sağlanmasında Devletin Etkinliği ve Türkiye Örneği", Dokuz Eylül Üniversitesi Sosyal Bilimler Enstitüsü Yayınlanmamış Doktora Tezi.

De Regil, Alvaro, 2001, "Keynesian Economics and the Welfare State, The Neo-capitalist Assoult", Global Economic Development Essay Series, Essay Four of Part I, pp.1-19.

Dikici Bilgin, Hasret, 2006. "Working Street Children in Turkey and Romania: A Comparative Historical Analysis in the Context of New Poverty", Sociology Department, Unpublished Master Thesis. Ankara: METU.

Dilnot, Andrew, 2003. "Refah Devletinin Geleceği" (Çev. Zeynel BakııI), <http://www.canaktan.org/politika/anti_leviathan/digeryazilar/bakici-refah-devleti.pdf>, pp. 1-16.

Ellwood, Wayne, 2002. Küreselleşmeyi Anlama Kılavuzu (Çev. Betül Dilan Genç), İstanbul: Metis Yayıncılık.

Ersoy, Melih ve H. Tarık Şengül, 2001. Kent, Göç ve Yoksulluk: Diyarbakır Örneği, ODTÜ Kentsel Politika Planlama ve Yerel Yönetimler Stüdyo Çalışması.

Ersöz, Halis Yunus, 2003. "Doğuşundan Günümüze Sosyal Politika Anlayışı", İktisat Fakültesi Mecmuası, Cilt.53, Sayı(2), ss. 119-145.

Galgster, George, 1992. "A Cumulative Causation Model of the Underclass: Implications For Urban Economic Development Policy, N.J.: The state university of New Jersey, Center for Urban Policy Research, pp:190-215.

Güler, Birgül Ayman, 2003. "ikinci Dalga: Siyasal ve Yönetsel Liberalizasyon, Kamu Yönetimi Temel Kanunu", AÜSBF Tartısma Metinleri, Sayı 59, Kasım 2003, ss.1-34.

Güler, Birgül Ayman, 2005. Yeni Sağ ve Devletin Değişimi: Yapısal Uyarlama Politikaları 1980-1995, Ankara: İmge Kitabevi Yayıncılık.

Güloğlu, Tuncay, 1998. "Genel Olarak ve Türkiye'de Yaşlı Nüfusun Sosyal Güvenliği", İstanbul Üniversitesi Sosyal Bilimler Enstitüsü, Yayınlanmamış Doktora Tezi, İstanbul.

Güzel, Ali and Ali Rıza Okur, 1990. Sosyal Güvenlik Hukuku, İstanbul: Beta Yayınları.

Hambleton,Robin, 1991. "American Dreams and Urban Realities", The Planner, Vol. 77, pp: 6-9.

Harvey, David, 1985. Urbanisation of Capital, John Hopkins University Press Baltimore.

Harvey, David, 1989. 'From Managerialism to Entrepreneurialism: The Transformation Governance in late Capitalism,' Geografiska Annaler, Vol. 71(1), pp.1-16.

Harvey, David, 2005. The Brief History of Neo-Liberalism. U.K.: Oxford University Press.

Hayami, Yujiro, 2003. "From Washington Consensus to the post-washington Consensus", FASID, No. 2003-001, Foundation for Advanced Studies on International Development.

Jessop, Bob, 2005. Hegemonya, Post-fordizm ve Küreselleşme Ekseninde Kapitalist Devlet (eds) Betül Yarar and Alev Özkazanç, Istanbul: lletişim yayınları.

Keyder, Çağlar, 2004. Ulusal Kalkınmacılığın Iflası, İstanbul: Metis Yayınları.

Koray, Meryem, 2003. "Sosyal Refah Devleti: Kimi İçin Umut, Kimi İ̧in Kaygı Kaynağı", Sosyal Demokrat Yaklaşımlar, İstanbul: SODEV-TÜSES Yayınları, ss. 93-113.

Kotz, David M., 2000. "Globalization and Neoliberalism", pp.1-25.<http:// people. umass. edu/dmkotz/Glob_and_NL_02.pdf> (Accessed 26 May 2015).

Köse, Ahmet Hasim, 2005. "Yapısal Reformlar Sermayenin Kurumlarını ve Hukukunu Olusturuyor", Toplum ve Hekim, Cilt 20, Sayı 1, ss. 36-40.

Kuhnle, Stein and M. Alestalo, 2000. "Growth, Adjustments and Survival of European Welfare States", in Survival of the European Welfare State, London: Routledge Publications.

Lister, Ruth, 2004. Poverty. UK Cambridge: Polity Press.

Logan,J.R.and H. Molotch, 1987. Urban Fortunes, Berkeley, CA: University of California Press. in Phil Hubbard, 1998. "The Entrepreneurial City: Geographies of Politics, Regime and Representation" (ed.) Tim Hall, John Wiley and Sons, Wiley Publications.MacPherson, Stewart and Richard Silburn, 1998. "The Meaning and Meaurement of Poverty", in Poverty: A Persistent Global Reality (eds) John Dixon, London: Oxford University Press.

Marshall, Thomas H., 1964. "Citizenship and Social Class", Class, Citizenship and Social Development, USA: Anchor Books

Mingione, Enzo, 1992. Fragmented Societies. Blackwell, U.K.: Oxford University Press.

Mollenkopfh, John H. and Manuel Castells, 1991. Dual City: Restructuring New York, NY: Sage.

Mullard, Maurice and Spicker, Paul, 1998. Social Policy in a Changing Society, London: Routledge.

Öniş, Ziya and Fikret Şenses, 2003. "Re-thinking the Emerging of Post-Washington Consensus: A Critical Appraisal", ERC Working Paper in Economics 03/09 November 2003, pp.1-36. 
Özdemir, Süleyman, 2007. Küreselleşme Sürecinde Refah Devleti, İstanbul Ticaret Odası Yayınları.

Painter, Joe, 1998. Entrepreneurs Are Made, Not Born: Learning And Urban Regimes In The Production Of Entrepreneurial Cities, p.260-261 in Phil Hubbard, 1998. "The Entrepreneurial City: Geographies of Politics, Regime and Representation" (ed.) Tim Hall, John Wiley and Sons. Wiley Publications.

Pal, A. Leslie, 1989. Public Policy Analysis: An Introduction, Chapter I Public Policy, Ont. Press: Scarborough.

Peck, Jamie and Adam Tickell, 1994. Jungle Law Breaks Out: Neo-Liberalism And Global-Local Disorder, Area, Vol. 26 (4), pp. 317-26.

Peterson, George, 1994. Decentralisation Experience in Latin America: An Overview of Lessons and Issues. The Urban Institute: Washington.

Pickvance, Chris and Edmond Preteceille, 1991. State Restructuring and Local Power: A Comparative Perspective, London,UK: Pinter, in Phil Hubbard, 1998. "The Entrepreneurial City: Geographies of Politics, Regime and Representation" (ed.) Tim Hall, John Wiley and Sons. Wiley Publications.

Rosenau, James N., 1992, "Governance, Order ad Change in World Politics" (ed.) J.N.

Sala, Vincent Della, 2001. "Constitutionalising Governance: Democratic Dead End or Dead On Democracy?" Conweb, Vol.6, pp.3-18.

Sallangül, Songül, 2006. Sosyal Devlet Bitti Yaşasın Piyasa, Ankara: Nobel Yayın.

Savran, Sungur, 1996. Küreselleşme mi Uluslararasılaşma mı? (1), Sinıf Bilinci Dergisi, Sayı:16-17, ss.37-79.

Selamoğlu, Ahmet, 2000, Yoğunlaşan Sosyal Sorunlarılla Küreselleşme, Küreselleşmenin İnsani Yüzü, (Eds) Veysel Bozkurt, İstanbul: Alfa Yayınları.

Sözer, Ali Nazım, 1994. Türkiye'de Sosyal Hukuk, Ankara: Kamu-Iş Yay.

SPO, 2001. "Sosyal Güvenlik Özel İhtisas Komisyonu Raporu", Sekizinci Beş Yıllık Kalkınma Planı, DPT Yayınları: Ankara.

Şengül, Tarık, 2004. "Yerel Devlet Sorunu ve Yerel Devletin Dönüşümünde Yeni Eğilimler" Praksis, No: 9, pp. 183-220.

Şenkal, Abdulkadir, 2005. Küreselleşme Sürecince Sosyal Politika, İstanbul: Alfa Yayınları.Tuna, Orhan and Nevzat Yalçıntaş, 1988. Sosyal Siyaset, İstanbul: Filiz Kitabevi.

WB, 1997. "WDR 1997: State in a Changing World". Washington D.C.: World Bank.

WB, 2000. World Development Report 2000/2001: Attacking Poverty. New York: Oxford University Press. 